\title{
FANCB wt Allele
}

National Cancer Institute

\section{Source}

National Cancer Institute. FANCB wt Allele. NCI Thesaurus. Code C86023.

Human FANCB wild-type allele is located in the vicinity of Xp22.2 and is approximately 30 $\mathrm{kb}$ in length. This allele, which encodes Fanconi anemia group B protein, may be involved in the modulation of both protein ubiquitination and DNA repair. Mutation of the gene is associated with Fanconi anemia. 